\title{
Eclogites with oceanic crustal and mantle signatures from the Bellsbank kimberlite, South Africa, part 2: $\mathrm{Sr}, \mathrm{Nd}$, and $\mathrm{O}$ isotope geochemistry
}

\author{
Clive R. Neal ${ }^{a}$, Lawrence A. Taylor ${ }^{a}$, Jon P. Davidson ${ }^{b, c}$, Peter Holden ${ }^{b . c}$, Alex N. Halliday ${ }^{b}$, \\ Peter H. Nixon ${ }^{\mathrm{d}}$, James B. Paces ${ }^{\mathrm{a}}$, Robert N. Clayton ${ }^{\mathrm{e}}$, and Toshiko K. Mayeda ${ }^{\mathrm{e}}$ \\ "Department of Geological Sciences, University of Tennessee, Knoxville, TN 37996 (U.S.A.) \\ ${ }^{h}$ Department of Geological Sciences, 1006 C.C. Little Building, University of Michigan, Ann Arbor, MI 48109 (U.S.A.) \\ "Department of Earth and Space Sciences, 3806 Geology Building, University of California, Los Angeles, CA 90024 (U.S.A.) \\ ${ }^{d}$ Department of Earth Sciences, The University, Leeds LS2 9JT (U.K.) \\ ${ }^{e}$ Enrico Fermi Institute, University of Chicago, Chicago, IL 60637 (U.S.A.)
}

Received September 11, 1989; revised version accepted April 9. 1990

\section{ABSTRACT}

The $\mathrm{Sr}, \mathrm{Nd}$, and $\mathrm{O}$ isotopic compositions of garnet and clinopyroxene mineral separates from nine eclogite xenoliths from the Bellsbank kimberlite (erupted at $120 \mathrm{Ma}$ ) define three groups. Group A eclogites, considered to be mantle cumulates, are characterized by $\delta^{18} \mathrm{O}$, and ${ }^{87} \mathrm{Sr} /{ }^{86} \mathrm{Sr}$ values typical of mantle-derived materials $(+5.1$ to $+5.6 \% 0$ and $0.7042-0.7046$, respectively), and very low $\mathrm{Sm} / \mathrm{Nd}$ ratios, (apparent) $\mathrm{Rb} / \mathrm{Sr}$ ratios and $\epsilon_{\mathrm{Nd}[120]}$ values $(0.057-0.078,0.00005-0.00136$ and -14 to -16 respectively). The REE and isotopic data for these eclogites can be modelled in terms of crystallization from a Group II kimberlite magma at $\sim 1-1.5 \mathrm{Ga}$. Group B and C eclogites, believed to be the metamorphosed products of ancient subducted oceanic crust, are characterized by low $\delta^{18} \mathrm{O}(+2.9$ to +4.7$)$, extremely high $\epsilon_{\mathrm{Nd}[120]}(\sim+40$ to +219$)$, and radiogenic ${ }^{87} \mathrm{Sr} /{ }^{86} \mathrm{Sr}$ ratios $(0.708-0.710)$. The $\mathrm{Sm} / \mathrm{Nd}$ ratios of the Group B eclogites are very high (up to 1.6). The data for Group $\mathrm{B}$ and $\mathrm{C}$ eclogites define a linear correlation on $\mathrm{Sm} / \mathrm{Nd}$ and $1 / \mathrm{Nd}$ vs. $\epsilon_{\mathrm{Nd}}[120]$ diagrams. These relationships are consistent with mixing of the Bellsbank kimberlite $\left(\epsilon_{\mathrm{Nd}[120]}=-10 ; \mathrm{Sm} / \mathrm{Nd}=0.10\right)$ with a depleted eclogite end-member $\left(\epsilon_{\mathrm{Nd}[120]}+219 ; \mathrm{Sm} / \mathrm{Nd}=1.6\right)$ during a cryptic metasomatic event. The $\mathrm{Sr}$ isotopic variations in Group B and $\mathrm{C}$ eclogites cannot be generated by simple two-component mixing. The $\mathrm{Sr}, \mathrm{Nd}$, and $\mathrm{O}$ isotope data for Group $\mathrm{B}$ and $\mathrm{C}$ eclogites probably reflect a complex sequence of depletion and enrichment events, in both crust and mantle settings. Enrichments which possibly affected the Group B and C eclogites include seawater-alteration of a MORB-like protolith, which lowered the $\delta^{18} \mathrm{O}$ and raised the ${ }^{87} \mathrm{Sr} /{ }^{86} \mathrm{Sr}$ ratio, but left the $\mathrm{Nd}$ isotopic compositions unchanged, and cryptic metasomatism by the magmatism that produced the Bellsbank kimberlite. The high $\mathrm{Sm} / \mathrm{Nd}$ ratio of the depleted eclogite end-member cannot be generated by extraction of a melt from a modern MORB composition. Rather, it is argued that such high $\mathrm{Sm} / \mathrm{Nd}$ ratios are produced as a result of partitioning during the recrystallization of a MORB-like component to eclogite during subduction. Nd model ages suggest that this process occurred $\sim 2.3-2.4 \mathrm{Ga}$.

\section{Introduction}

Eclogite xenoliths found in kimberlites and alkali basalts are essentially composed of garnet and clinopyroxene that crystallized (or recrystallized) at high pressures. However, within this general definition, a significant range of mineralogic, isotopic, and chemical compositions exists. This variation has led to three models for eclogite petrogenesis, which propose that eclogites formed as: (1) high-pressure igneous cumulates (garnet pyrox- enites) occurring as mafic dikes emplaced within the upper mantle [3-8]; (2) the metamorphic products of a subducted oceanic crustal protolith [1,2,9-19]; and (3) relicts of the Earth's primary differentiation shortly after accretion [20-23]. This hypothesis requires that the Earth was partially molten during early evolution, similar to the Lunar Magma Ocean theory proposed for the Moon $[24,25]$.

Eclogite xenoliths have been subdivided on the basis of major and trace element data $[1,2,4,12$, 
$13,16]$. Shervais et al. $[1,17,18]$ examined eclogites from several kimberlites and identified three groups of mantle eclogite xenoliths each with apparently different petrogenetic histories. One group was thought to be a product of high pressure crystallization of a basaltic melt (Group A). It was hypothesized that the other two (Groups B and $C$ ) represented different portions of subducted oceanic lithosphere. These conclusions [1] were based on a small number of samples collected over a broad geographic area and the observed compositional differences could be related to lateral heterogeneity in the eclogite source. The present work represent a more detailed geochemical study of eclogite xenoliths collected from a single kimberlite and hence a study of vertical heterogeneity to test the validity of previous hypotheses.

Taylor and Neal [2] demonstrated that there are three eclogite groups in the Bellsbank kimberlite, situated in the Barkly West district, Cape Province of the RSA. This kimberlite erupted at $120 \mathrm{Ma}$ [30]. Taylor and Neal [2] further argued that the three eclogite groups could not be related to each other by any reasonable fractional crystallization scheme, supporting the tentative conclusions of Shervais et al. [1]. An eclogite classification similar to that of Coleman et al. [26] was used in order to be consistent with the three-fold division already prevalent in the literature:

Group $A$ : primary orthopyroxene or olivine present as an accessory phase; many triple junctions between constituent grains; low jadeite component in clinopyroxene; $\mathrm{Mg}$ - and $\mathrm{Cr}$-rich garnets; Cr-rich clinopyroxene; high whole-rock MG \#'s; LREE-enriched clinopyroxenes and reconstructed whole-rocks.

Group B: moderate jadeite component in clinopyroxene; Fe-rich garnets; slight LREE-enrichment in clinopyroxenes; extreme LREE-depleted/HREE-enriched garnets; low concentrations of incompatible trace elements in the reconstructed whole-rocks.

Group $C$ : primary kyanite present as an accessory phase; high jadeite component in clinopyroxene; Ca-rich garnets; positive Eu anomaly present in REEs from both garnet and clinopyroxene; Al-rich whole-rock compositions; low REE abundances in both clinopyroxene and garnet.

Radiogenic and stable isotope studies have al- ready been used to elucidate the petrogenesis of kimberlitic eclogite xenoliths. Early attempts to interpret $\mathrm{Pb}$ and $\mathrm{Sr}$ isotope signatures from southern African eclogites were based on whole-rock data [27-29]. Analysis of ultrapure mineral separates has illustrated that whole-rock isotopic compositions largely reflect secondary, metasomatic mineral phases, rather than the primary phases of garnet and clinopyroxene [12,13]. Results of these studies have indicated that many eclogite xenoliths have extreme isotopic compositions. Values for $\epsilon_{\mathrm{Nd}[\text { Present] }}$ in excess of 200 epsilon units have been reported from eclogites in South African kimberlites $[1,12,13,23]$. The extreme isotopic signatures found in eclogites have been used to argue in favor of each of the above models of eclogite petrogenesis (e.g., $[1,12,13,17$, $18,22,23])$. These eclogites contain the highest ${ }^{143} \mathrm{Nd} /{ }^{144} \mathrm{Nd}$ of any mantle material and require an ancient LREE-depletion to produce high $\mathrm{Sm} / \mathrm{Nd}$ and ${ }^{143} \mathrm{Nd} /{ }^{144} \mathrm{Nd}$ ratios. Since the eclogites potentially represent material metamorphosed and depleted in the LREE at extreme pressures, it is possible that the bulk composition is far removed from that of its protolith. However, the chemical signatures of the eclogites allow their petrogenesis to be defined. In this paper we investigate this possibility and attempt to determine on isotopic grounds, what the nature of both the protolith and the depletion processes may have been.

Six eclogites from the Debruyn and Martin Mine of the Bellsbank eclogite group were specifically selected for isotopic analysis on the basis of being the least affected by secondary metasomatic and hydrothermal alteration, and representative of all three eclogite groups outlined above. Data from the three Bellsbank xenoliths reported by Shervais et al. [1] have also been included for the sake of completeness and to facilitate comparison.

\section{Sample preparation and analytical techniques}

All of the Bellsbank eclogites have experienced metasomatism [2]. The pervasive effects of this metasomatism required special procedures in order to distinguish between primary and secondary geochemical characteristics. It was essential that "ultrapure" garnet and clinopyroxene separates be prepared in order to determine: (a) the closest representation of primary phase compositions; and 
(b) the contributions to the whole-rock composition from any secondary process [2].

Each eclogite sample was crushed to $<250 \mu \mathrm{m}$ and washed with dilute $\mathrm{HCl}$. A rough separation of garnet and clinopyroxene was then made with a Franz magnetic separator. These separates were then handpicked under the binocular microscope using a circular light source. Crystals with imperfections or adhering mineral fragments were discarded. The semi-pure separate was then twice leached with acid in an ultrasonic bath. The first leach was in $6 \mathrm{M} \mathrm{HCl}$ and the second in an $\mathrm{HF} / \mathrm{HNO}_{3}(20: 80)$ mixture. Each separate was re-picked between leaches. As a final check for purity, $10 \mathrm{mg}$ from each separate was analyzed (at the Johnson Space Center, Houston) for K, an element that fingerprints metasomatic or kimberlitic contamination (i.e., through the introduction of phlogopite and/or amphibole). Each separate contained $<0.5 \mathrm{ppm} \mathrm{K}$ indicating the ultrapure nature of our mineral separates. Finally, each of the separates (each of $100-160 \mathrm{mg}$ ) was split into three portions for analysis: (1) for trace elements by INAA (reported by [2]; (2) for oxygen isotopic analysis; and (3) for $\mathrm{Sr}$ and $\mathrm{Nd}$ isotopic analysis.

All of the new $\mathrm{Sr}$ and $\mathrm{Nd}$ isotopic data presented here were obtained, using standard procedures, in the Radiogenic Isotope Geochemistry Laboratory (RIGL) at the University of Michigan. Sample solutions were split into an unspiked and a spiked aliquot. Isotopic measurements were made on a V.G. Sector mass spectrometer using multi-dynamic routines. Results of standards obtained during the period of study were ${ }^{87} \mathrm{Sr} /{ }^{86} \mathrm{Sr}$ of $0.710242 \pm 8 \quad(2$ sigma mean, $N=13)$ for NBS987, and ${ }^{143} \mathrm{Nd} /{ }^{144} \mathrm{Nd}$ of $0.511855(N=18)$ for the La Jolla standard. ${ }^{87} \mathrm{Sr} /{ }^{86} \mathrm{Sr}$ ratios are presented normalized to ${ }^{86} \mathrm{Sr} /{ }^{88} \mathrm{Sr}$ of 0.1194 . ${ }^{143} \mathrm{Nd} /{ }^{144} \mathrm{Nd}$ ratios are presented normalized to ${ }^{146} \mathrm{Nd} /{ }^{144} \mathrm{Nd}$ of 0.7219 . Power law fractionation corrections were used throughout. Isotope dilution concentration measurements are accurate to $1 \%$. $\mathrm{Sm} / \mathrm{Nd}$ ratio measurements are accurate to better than $0.3 \% . \mathrm{Rb} / \mathrm{Sr}$ ratio measurements are accurate to better than $1 \%$. Total procedure blanks were $<50 \mathrm{pg}$ for $\mathrm{Rb}, \mathrm{Sr}, \mathrm{Sm}$, and $\mathrm{Nd}$. The isotopic ratios are sometimes discussed relative to Bulk Earth (Present Day $={ }^{87} \mathrm{Sr} /{ }^{86} \mathrm{Sr}=0.7045$, ${ }^{87} \mathrm{Rb} /{ }^{86} \mathrm{Sr}=0.0925,{ }^{143} \mathrm{Nd} /{ }^{144} \mathrm{Nd}=0.512638$, $\left.{ }^{147} \mathrm{Sm} /{ }^{144} \mathrm{Nd}=0.1966\right)$.
Oxygen isotopic compositions were determined at the Enrico Fermi Institute, University of Chicago, by the $\mathrm{BrF}_{5}$ method of Clayton and Mayeda [31]. Garnet reacts relatively slowly with $\mathrm{BrF}_{5}$; oxygen yields of $80-100 \%$ were obtained in two-day reactions at $700^{\circ} \mathrm{C}$. Most of the samples were mass analyzed as $\mathrm{CO}_{2}$ to determine $\delta^{18} \mathrm{O}$. Four samples with low $\delta^{18} \mathrm{O}$ were analyzed as $\mathrm{O}_{2}$ to determine both $\delta^{18} \mathrm{O}$ and $\delta^{17} \mathrm{O}$. All fell within $\pm 0.1 \%$ of the terrestrial fractionation line, thus verifying that the low ${ }^{18} \mathrm{O}$ effects are due to ordinary mass-dependent fractionation, and not to mixing with some exotic component.

\section{Isotopic composition of the Bellsbank eclogites}

$\mathrm{Sr}$ and $\mathrm{Nd}$ isotopic compositions were determined on whole-rocks (Table 2), as well as ultrapure garnet and clinopyroxene mineral separates (Table 1), where possible. Garnets from mantle xenoliths have extremely low $\mathrm{Sr}$ concentrations, which means that ultrapure separates are required in order to obtain uncontaminated $\mathrm{Sr}$ isotopic compositions [32].

Mineral isotopic ratios have been age-corrected to $120 \mathrm{Ma}$, the age of eruption of the Bellsbank kimberlite reported by Smith [30]. Although all six garnet separates in this study were analyzed for their $\mathrm{Sr}$ isotopic compositions, the garnet from PHN2791-34 failed to yield reproducible results because of small sample size. Unfortunately, garnets from the three eclogites analyzed by Shervais et al. $[1,17,18]$, and included in this present study, were not analyzed for $\mathrm{Sr}$ isotopic ratios due to lack of sufficient sample.

\subsection{Group $A$}

Group A clinopyroxenes possess low ${ }^{143} \mathrm{Nd} /$ ${ }^{144} \mathrm{Nd}_{[120]}\left(\epsilon_{\mathrm{Nd}[120]} \sim-18\right.$ : Fig. 1, Table 1), compatible with their LREE-enriched character [2]. These samples contain the highest absolute REE abundances $(\mathrm{Nd}=13.1-22.1 \mathrm{ppm} ; \mathrm{Sm}=0.70$ $1.47 \mathrm{ppm}$ ) as well as the lowest ${ }^{147} \mathrm{Sm} /{ }^{144} \mathrm{Nd}$ ratios (0.032-0.040) reported from our Bellsbank eclogite suite. These $\mathrm{Sm} / \mathrm{Nd}$ ratios are among the lowest reported for clinopyroxenes from mantle xenoliths. The Sr isotopic compositions $\left({ }^{87} \mathrm{Sr} /{ }^{86} \mathrm{Sr}\right.$ $=0.70374-0.70420$ ) are slightly lower than values expected for the model Bulk Earth at $120 \mathrm{Ma}$ (Table 1, Fig. 1). Although $\mathrm{Sr}$ abundances are 


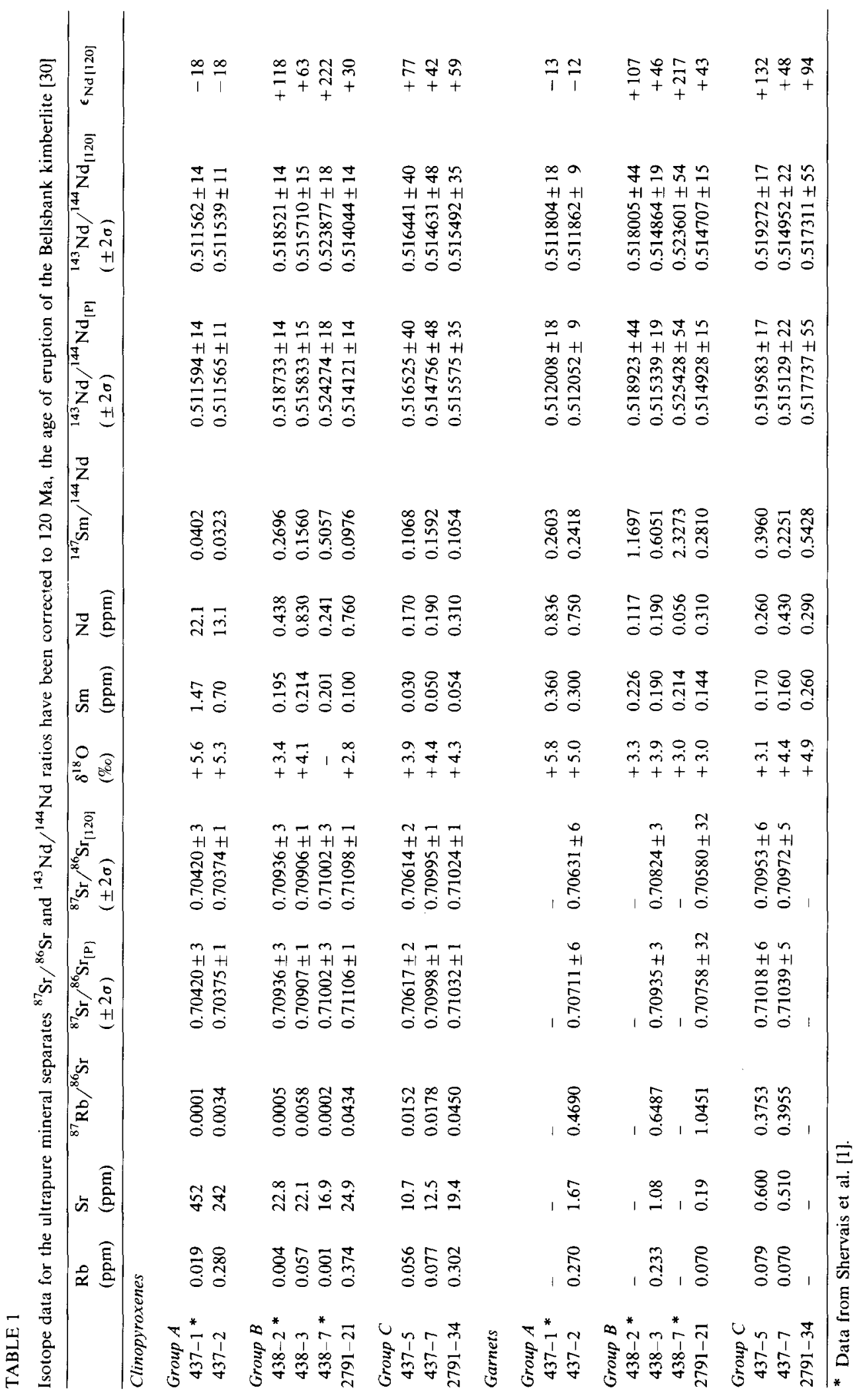


TABLE 2

Selected whole-rock isotope data; ratios are present-day values

\begin{tabular}{lllr}
\hline & ${ }^{87} \mathrm{Sr} /^{86} \mathrm{Sr} \pm 2 \sigma$ & ${ }^{143} \mathrm{Nd}{ }^{144} \mathrm{Nd} \pm 2 \sigma$ & $\epsilon_{\mathrm{Nd}}$ \\
\hline Group $A$ & & & -17 \\
$437-2$ & $0.70692 \pm 1$ & $0.511417 \pm 8$ & -17 \\
Leach * & $0.71362 \pm 1$ & $0.511785 \pm 12$ & -19 \\
Residue & $0.70416 \pm 1$ & $0.511644 \pm 11$ & \\
Group B & & & -3 \\
438-3 & $0.71284 \pm 10$ & $0.512494 \pm 21$ & -6 \\
Leach * & $0.71635 \pm 3$ & $0.512343 \pm 8$ & -2 \\
Residue & $0.70772 \pm 5$ & $0.512553 \pm 12$ & -5 \\
2791-21 & - & $0.512387 \pm 15$ & -9 \\
Leach * & $0.71530 \pm 2$ & $0.512187 \pm 16$ & +3 \\
Residue & $0.70871 \pm 2$ & $0.512783 \pm 13$ & - \\
Group C & & & -5 \\
437-5 & $0.72629 \pm 1$ & - & +1 \\
Leach * & $0.72694 \pm 1$ & $0.512385 \pm 11$ & -8 \\
Residue & $0.71161 \pm 3$ & $0.512699 \pm 12$ & -10 \\
437-7 & $0.72534 \pm 1$ & $0.512227 \pm 29$ & - \\
Leach * & $0.72650 \pm 1$ & $0.512123 \pm 13$ & -10 \\
Residue & $0.70950 \pm 1$ & $0.512723 \pm 9$ & +2 \\
2791-34 & $0.71825 \pm 1$ & - & \\
Leach * & $0.72066 \pm 4$ & $0.512099 \pm 9$ & \\
Residue & $0.70783 \pm 3$ & $0.512761 \pm 10$ & \\
\hline
\end{tabular}

${ }^{*}$ Hot $6 N \mathrm{HCl}$ for 24 hours.

relatively high (241-452 ppm; Table 1), Rb abundances are very low $(0.10-0.21 \mathrm{ppm}$; Table 1$)$, resulting in very low ${ }^{87} \mathrm{Rb} /{ }^{86} \mathrm{Sr}$ ratios. Therefore,

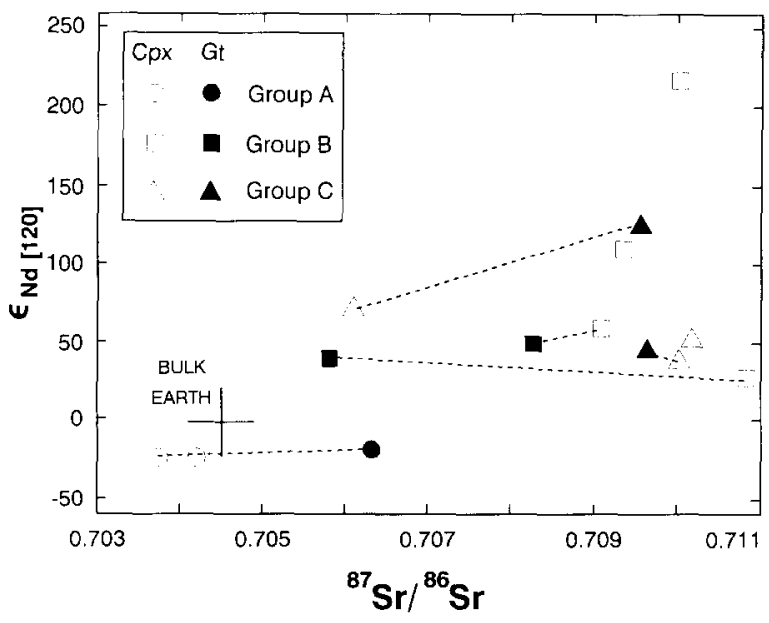

Fig. 1. $\epsilon_{\mathrm{Nd}}$ vs. ${ }^{87} \mathrm{Sr} /{ }^{86} \mathrm{Sr}$ for garnet and clinopyroxene pairs. All ratios are corrected to $120 \mathrm{Ma}$, the age of eruption of the Bellsbank kimberlite [30]. Tie lines connect minerals from the same eclogite. Garnets for which only $\mathrm{Nd}$ isotopes were analyzed have not been plotted. Errors are generally smaller than the size of the symbol used. there has been little change in the ${ }^{87} \mathrm{Sr} /{ }^{86} \mathrm{Sr}$ ratio since kimberlite eruption at $120 \mathrm{Ma}$ due to in-situ radioactive decay. Oxygen isotopic compositions (Table 1) of Group A clinopyroxenes are confined to a small range of $\delta^{18} \mathrm{O}$ values $(+5.3$ to $+5.6 \%$ ), which is typical of mantle-equilibrated materials [33-36].

The garnets from Group A eclogites also contain unradiogenic $\mathrm{Nd}\left(\epsilon_{\mathrm{Nd}}=-12\right.$ to -13 ; Table 1, Fig. 1), which reflects the LREE-enriched nature of the whole-rocks (see below). Although both $\mathrm{Sm}$ and $\mathrm{Nd}$ abundances are very low $(0.30-0.36$ $\mathrm{ppm}$ and $0.75-0.84 \mathrm{ppm}$, respectively), $\mathrm{Sm} / \mathrm{Nd}$ ratios are high, as expected from garnet partitioning of REEs. Only one Group A garnet was analyzed for its $\mathrm{Sr}$ isotopic composition (FRB4372), yielding an ${ }^{87} \mathrm{Sr} /{ }^{86} \mathrm{Sr}$ ratio (0.7063; Fig. 1) which is substantially more radiogenic than that of the co-existing clinopyroxene. As expected from partition coefficients for garnet, $\mathrm{Rb}$ and $\mathrm{Sr}$ are both present in relatively low abundances $(0.27$ and $1.67 \mathrm{ppm}$, respectively), although $\mathrm{Rb} / \mathrm{Sr}$ is high relative to the clinopyroxenes. Oxygen isotopic compositions are similar to those of the clinopyroxenes, the $\delta^{18} \mathrm{O}$ ranging from +5.0 to $+5.8 \%$, again within accepted ranges of mantle values [33-36].

\subsection{Group B}

All Group B clinopyroxenes possess extremely high ${ }^{143} \mathrm{Nd} /{ }^{144} \mathrm{Nd}_{[120]}\left(\epsilon_{\mathrm{Nd}[120]}=+30\right.$ to +222 ; Fig. 1, Table 1), but only two samples (FRB438-2 and FRB438-7) have $\mathrm{Sm} / \mathrm{Nd}$ ratios greater than chondritic. As noted by Taylor and Neal [2], the total LREE abundances in Group B clinopyroxenes are lower than in Group A (Table 1), with $\mathrm{Sm}$ ranging from 0.10 to $0.21 \mathrm{ppm}$, and $\mathrm{Nd}$ from 0.24 to $0.83 \mathrm{ppm}$. Clinopyroxenes from Group B eclogites have ${ }^{87} \mathrm{Sr} /{ }^{86} \mathrm{Sr}$ ratios $(0.70906-0.71098)$ which are very high relative to Bulk Earth. As with Group A clinopyroxenes, low $\mathrm{Rb}$ abundances (0.001-0.374 ppm; Table 1) relative to $\mathrm{Sr}(16.9$ $28.1 \mathrm{ppm})$ result in extremely low ${ }^{87} \mathrm{Rb} /{ }^{86} \mathrm{Sr}$ ratios $(0.00017-0.0150)$. These ratios are not capable of generating the observed ${ }^{87} \mathrm{Sr} /{ }^{86} \mathrm{Sr}$ ratios from either a Bulk Earth or a depleted mantle ratio, even over the age of the Earth, assuming none of the primary $\mathrm{Rb}$ was removed during leaching. The $\delta^{18} \mathrm{O}$ values of these clinopyroxenes are lower than those reported for Group A $(+2.8$ to $+4.1 \%$; 
Table 1), and lie well below the proposed range of typical mantle values [33-36].

Like the clinopyroxenes, all Group B garnets contain extremely high ${ }^{143} \mathrm{Nd} /{ }^{144} \mathrm{Nd}_{[120]}\left(\epsilon_{\mathrm{Nd}}[120]\right.$ $=+43$ to +217 ), but the garnets also exhibit very high $\mathrm{Sm} / \mathrm{Nd}$ ratios $(0.45-3.8$; Table 1 , Fig. 1$)$. Both $\mathrm{Sm}$ and $\mathrm{Nd}$ are present below the $1 \mathrm{ppm}$ level (0.14-0.23 and 0.06-0.31 ppm, respectively). Two out of the four Group B garnets have been analyzed for their $\mathrm{Sr}$ isotopic composition. Garnet ${ }^{87} \mathrm{Sr} /{ }^{86} \mathrm{Sr}$ ratios also exhibit an enrichment in ${ }^{87} \mathrm{Sr} /{ }^{86} \mathrm{Sr}$ relative to Bulk Earth values $(0.7058$ 0.7082; Table 1, Fig. 1). $\mathrm{Rb}$ and $\mathrm{Sr}$ concentrations are low (0.07-0.23 and 0.19-1.08 ppm, respectively). Oxygen isotope measurements on these garnets agree closely with coexisting clinopyroxene and reflect unusually low $\delta^{18} \mathrm{O}$ values ranging from +3.0 to $3.9 \%$ (Table 1 ).

\subsection{Group $C$}

Like Group B clinopyroxenes, those from Group $\mathrm{C}$ have high ${ }^{143} \mathrm{Nd} /{ }^{144} \mathrm{Nd}_{[320]}\left(\epsilon_{\mathrm{Nd}[120]}=\right.$ +42 to +77 ; Fig. 1). Although Group $\mathrm{C}$ clinopyroxenes contain the lowest absolute REE abundances $(\mathrm{Sm}=0.03-0.05 \mathrm{ppm} ; \mathrm{Nd}=0.17-0.31$ $\mathrm{ppm}$ ), they are LREE-enriched [2]. The low $\mathrm{Sm} / \mathrm{Nd}$ ratios are incapable of accounting for the high ${ }^{143} \mathrm{Nd} /{ }^{144} \mathrm{Nd}$ ratios. The ${ }^{87} \mathrm{Sr} /{ }^{86} \mathrm{Sr}$ ratios of the Group $\mathrm{C}$ clinopyroxenes are also similar to those of Group B (0.7061-0.7102; Table 1, Fig. 1). Sr abundances in Group C clinopyroxenes (12-19 ppm) are slightly lower than those in Group B, while the low $\mathrm{Rb}$ abundances $(0.056-0.30 \mathrm{ppm})$ overlap those in Group B. Again, the low $\mathrm{Rb} / \mathrm{Sr}$ ratios measured in these clinopyroxenes would be unable to generate the ${ }^{87} \mathrm{Sr} /{ }^{86} \mathrm{Sr}$ in these minerals by in-situ decay of ${ }^{87} \mathrm{Rb}$. The range of $\delta^{18} \mathrm{O}$ values overlaps that from Group B clinopyroxenes $(+3.9$ to $4.3 \%$; Table 1 ), which is again below the range of normally accepted mantle values [33-36].

Isotopic ratios of Group $\mathrm{C}$ garnets $\left({ }^{87} \mathrm{Sr} /\right.$ ${ }^{86} \mathrm{Sr}_{[120]}=0.7095-0.7097 ;{ }^{143} \mathrm{Nd} /{ }^{144} \mathrm{Nd}_{[120]}=$ $0.514952-0.519272 ; \epsilon_{\mathrm{Nd}[120]}=+48$ to +132$)$ are compatible with the data for the coexisting clinopyroxenes and the garnets in Group B eclogites, although their values are not quite as extreme (Table 1, Fig. 1). Group C garnets possess typical HREE-enriched patterns [2] and have high $\mathrm{Sm} / \mathrm{Nd}$ ratios $(0.372-0.897)$. Two out of the three Group $\mathrm{C}$ garnets have been analyzed for their $\mathrm{Sr}$ isotopic compositions. The radiogenic ${ }^{87} \mathrm{Sr} /{ }^{86} \mathrm{Sr}$ ratios present in these garnets are similar to both Group $\mathrm{B}$ and $\mathrm{C}$ clinopyroxenes and Group $\mathrm{B}$ garnets (Table 1, Fig. 1). The oxygen isotopic compositions of these garnets $(+3.1$ to $+4.9 \%$; Table 1$)$ are generally lower than accepted mantle values.

\subsection{Whole-rocks}

The data presented above on the "ultrapure" mineral separates are assumed to reflect the compositions of the eclogite protolith without contamination introduced by "patent" metasomatic alteration (i.e. addition of new metasomatic phases) by the kimberlite host magma. This patent metasomatism was discussed by Taylor and Neal [2]. In order to gauge the contribution of the metasomatic phases observed in these xenoliths (i.e., phlogopite and amphibole; [2]), selected whole-rocks were analyzed for $\mathrm{Sr}$ and $\mathrm{Nd}$ isotopic ratios (Table 2). All whole-rock analyses yielded $\mathrm{Sr}$ isotopic compositions that were more radiogenic and $\mathrm{Nd}$ isotope ratios that were less radiogenic than those of the garnet and clinopyroxene mineral separates. None of the three groups may be distinguished on the basis of these data. After leaching, two eclogite residues (FRB483-3 and PHN2791-34) possess lower ${ }^{87} \mathrm{Sr} /{ }^{86} \mathrm{Sr}$ ratios than the reconstructed whole-rocks (Tables 2 and 3). These results may appear to be inconsistent and lead one to question the purity of the mineral separates. However, these same residues possess $\epsilon_{\mathrm{Nd} \text { [Present] }}$ values of -2 and +2 , quite unlike the highly positive values of the reconstructed wholerocks, indicating that the data for the residues do not represent the primary eclogite isotopic signature. Leaching in hot $6 M \mathrm{HCl}$ for two hours appears to have removed some of the $\mathrm{Sr}$, but little of the $\mathrm{Nd}$ contamination (Table 2). We suggest that the $\mathrm{HCl}$ leaching removed only a radiogenic Sr contaminant, leaving a relatively unradiogenic $\mathrm{Sr}$ and $\mathrm{Nd}$ component in the residue. Preparation of the mineral separates by rigorous leaching and handpicking removes this unradiogenic contamination.

Taylor and Neal [2] concluded that the metasomatic phases were introduced from the kimberlite magmatism. The Bellsbank kimberlite has been classified as a Group II micaceous kimberlite, with initial ${ }^{87} \mathrm{Sr} /{ }^{86} \mathrm{Sr}$ and ${ }^{143} \mathrm{Nd} /{ }^{144} \mathrm{Nd}$ ratios of 0.7085 and 0.51214 , respectively [30]. 


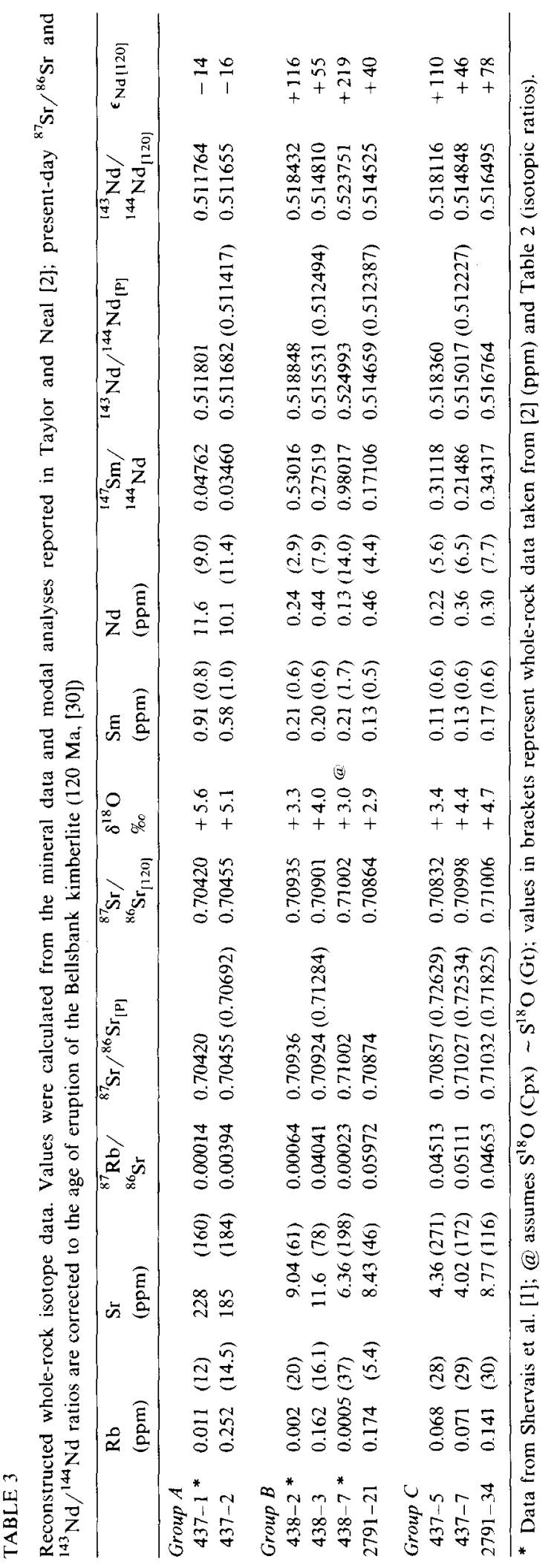


These kimberlites have initial ${ }^{87} \mathrm{Sr} /{ }^{86} \mathrm{Sr}$ and ${ }^{143} \mathrm{Nd} /{ }^{144} \mathrm{Nd}$ ratios which are respectively higher and lower than Bulk Earth values. In general, the eclogite whole-rocks have ${ }^{87} \mathrm{Sr} /{ }^{86} \mathrm{Sr}_{[120]}$ ratios greater than the host kimberlite [30]. We suspect that this may be partly attributable to post-emplacement weathering and alteration of the whole-rock material, but the exact explanation is unclear.

\subsection{Reconstructed whole-rocks}

In view of the evidence that even the leached whole rock samples remain severely contaminated, the isotopic compositions and parent/daughter ratios of whole rock eclogites (Table 3 ) have been reconstructed from the mineral separate data, in a similar manner as for the REE profiles [2]. The primary modal mineralogy and isotopic analyses of the ultrapure mineral separates were used in these calculations. Modes were determined by point counting and noting the association of metasomatic with primary phases. Where there was no $\mathrm{Sr}$ isotopic analysis for garnet, it was assumed that the ${ }^{87} \mathrm{Sr} /{ }^{86} \mathrm{Sr}$ ratio of the clinopyroxene represented that of the primary whole-rock and that garnet contained no appreciable $\mathrm{Rb}$ or Sr.

The reconstructed whole rock compositions are shown plotted on an $\epsilon_{\mathrm{Nd}}$ vs. ${ }^{87} \mathrm{Sr} /{ }^{86} \mathrm{Sr}$ diagram,

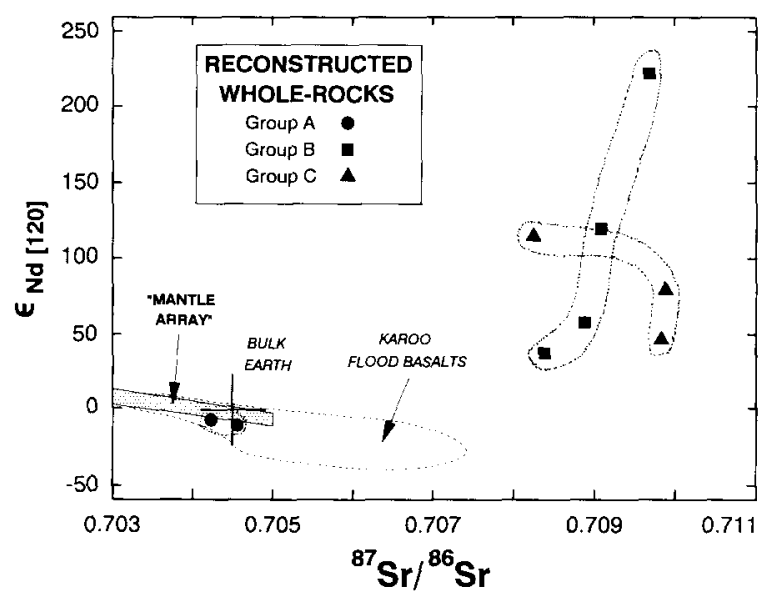

Fig. 2. $\epsilon_{\mathrm{Nd}}$ vs. ${ }^{87} \mathrm{Sr} /{ }^{86} \mathrm{Sr}$ for the reconstructed whole-rock eclogites. Values are calculated from isotope ratios of the mineral separates and primary modes (Table 1). Karoo data from Hawkesworth et al. [38]. All isotopic ratios are corrected to the age of eruption of the Bellsbank kimberlite (120 Ma [30]). age-corrected to $120 \mathrm{Ma}$, the Bellsbank kimberlite eruption age (Fig. 1). The Group A eclogites plot close to the "mantle array", near the region occupied by the Karoo flood basalts [38]. In contrast, the Group $\mathrm{B}$ and $\mathrm{C}$ eclogites plot in the upper right hand quadrant, as they contain both radiogenic $\mathrm{Sr}$ and $\mathrm{Nd}$.

The oxygen isotope values of the Group A eclogites are typical of mantle $\delta^{18} \mathrm{O}$ values. The Group B and C eclogites contain $\delta^{18} \mathrm{O}$ values that are unusually low compared with accepted mantle values [33-35].

\section{Generation of the eclogite isotopic signatures}

The results presented above demonstrate that the Bellsbank eclogite groups are not related to one another by a simple igneous fractionation process, contrary to the suggestion by Smyth et al. [8]. The extreme $\epsilon_{\mathrm{Nd}[120]}$ values and $\mathrm{Sm} / \mathrm{Nd}$ ratios in some Group B eclogites are among the highest yet reported, suggesting that processes involving assimilation of typical mantle or crustal compositions are also unlikely to account for the eclogite compositions. Therefore, both variable and complex petrogenetic processes are required to account for the origins of the different eclogite groups. It is important to note that the $\mathrm{Sr}, \mathrm{Nd}$, and $\mathrm{O}$ isotopic compositions of the Bellsbank Group A and B eclogites reported here are consistent with those reported by Shervais et al. $[1,17,18]$. Throughout the following discussion, the isotopic values refer to the reconstructed whole-rocks unless otherwise stated.

\subsection{Group $A$}

The Group A eclogites possess $\delta^{18} \mathrm{O}$ values that are typical of mantle-derived or mantle-equilibrated materials (Tables 1 and 3), as well as ${ }^{87} \mathrm{Sr} /{ }^{86} \mathrm{Sr}$ ratios that are similar to ocean island basalts [e.g., 39,40] and Group I kimberlites [30]. However, the negative $\epsilon_{\mathrm{Nd}[120]}(-14$ to -16$)$, although somewhat extreme, is more akin to continental flood basalts [e.g., 38] and Group II kimberlites [30] (Fig. 2; Tables 1 and 3).

Shervais et al. [1] proposed that the Group A eclogites were the high pressure cumulate products of a magma crystallizing in the mantle, based upon garnet-clinopyroxene $\mathrm{Kd}$ values. This suggestion is supported by the high $\mathrm{MG} \#$ ob- 
served by Taylor and Neal [2]. However, the overall LREE-enriched nature of these eclogites $(\mathrm{Sm} / \mathrm{Nd} \sim 0.07$ from the reconstructed wholerock composition) appears to contradict this conclusion, given the nature of the crystal/liquid $\mathrm{Kd}$ 's for the REEs in garnet and clinopyroxene [e.g., 41-44].

In order for a Group A eclogite to be a mantle cumulate product, the parental magma must have been highly LREE-enriched, if the REEs have not been subsequently added by cryptic metasomatic exchange. Calculations using published mineral/ liquid partition coefficients and modal analyses demonstrate that this magma, while fractionating garnet and clinopyroxene in the proportions reported in Taylor and Neal [2], must possess a $\mathrm{Sm} / \mathrm{Nd}$ ratio of approximately 0.05 (Table 4). Magmas with this $\mathrm{Sm} / \mathrm{Nd}$ could have been similar to those reported for micaceous or Group II kimberlites [e.g., 30,45,46]. These Group A eclogites can be adequately modeled by crystallizing the observed primary modes of garnet and clinopyroxene from a Group II kimberlite magma (Table 4).

Although trace element modeling supports crystallization of Group A eclogites from Group II-like kimberlitic magmas (Table 4), the dichotomy of $\mathrm{Nd}$ and $\mathrm{Sr}$ isotopic data from these xenoliths with those of Group II kimberlites appear to conflict with a simple fractionation model if the Bellsbank kimberlite is taken as the parent. How- ever, $\mathrm{Sr}$ and $\mathrm{Nd}$ isotopic compositions at the time of kimberlite eruption (120 Ma, [30]) for the Group A eclogites (or their protolith) are the time-integrated results of low $\mathrm{Rb} / \mathrm{Sr}$ ratios and low $\mathrm{Sm} / \mathrm{Nd}$ ratios in these cumulates.

The evolution paths of the Group A eclogites and Group II kimberlites have been calculated and are shown on an $\epsilon-\epsilon$ plot (Fig. 3). Observed ${ }^{87} \mathrm{Rb} /{ }^{86} \mathrm{Sr}$ and ${ }^{147} \mathrm{Sm} /{ }^{144} \mathrm{Nd}$ ratios were used for the Group A eclogites, and Group II kimberlites spanning the range of $\mathrm{Sr}$ isotope values were taken from Smith [30]. Assuming that kimberlite magmatism did not affect these ratios (because of their high $\mathrm{Sr}$ and $\mathrm{Nd}$ contents and the ultrapure nature of the mineral separates), the evolution paths of the Group A eclogites and Group II kimberlites intersect at approximately 1.15-1.40 Ga (Fig. 3). The Group A eclogite evolution line would not be as steep if primary $\mathrm{Rb}$ has been leached from the mineral separates. Therefore, the age of intersection with the Group II kimberlite evolution paths must be regarded as a maximum age. This relationship is supported by $\mathrm{Nd}$ model age calculations for reconstructed Group A eclogite wholerock compositions. These calculations yield $T_{\text {CHUR }}$ model ages of $-950 \mathrm{Ma}$, and $T_{\mathrm{DM}}$ model ages of $-1300 \mathrm{Ma}$.

From the isotopic and REE data, we infer that Group A eclogites crystallized at $1 \pm 0.2 \mathrm{Ga}$ from magmas derived from a Group II kimberlite source. The isotopic compositions of the melts

\section{TABLE 4}

Cumulate modeling for the petrogenesis of Group A eclogites from a Group II kimberlite magma

\begin{tabular}{|c|c|c|c|c|c|c|c|}
\hline & Garnet & Cpx & Opx & Olivine & Bulk D & Parental magma & Cumulate \\
\hline $\mathrm{Kd} \mathrm{Sm}$ & 0.131 & 0.295 & 0.047 & 0.0066 & 0.21179 & & \\
\hline $\mathrm{Kd} \mathrm{Nd}$ & 0.026 & 0.258 & 0.034 & 0.0066 & 0.14264 & & \\
\hline Mode ${ }^{1}$ & 48.1 & 50.4 & 0 & 1.5 & & & \\
\hline $\mathrm{Sm}^{1}$ & & & & & & 5 & 1.06 \\
\hline $\mathrm{Nd}{ }^{1}$ & & & & & & 100 & 14.26 \\
\hline $\mathrm{Sm} / \mathrm{Nd}^{1}$ & & & & & & 0.050 & 0.074 \\
\hline Mode $^{2}$ & 14.7 & 76.6 & 8.7 & 0 & & & \\
\hline $\mathrm{Sm}^{2}$ & & & & & & 5 & 1.25 \\
\hline $\mathrm{Nd}^{2}$ & & & & & & 100 & 20.44 \\
\hline $\mathrm{Sm} / \mathrm{Nd}^{2}$ & & & & & & 0.050 & 0.061 \\
\hline
\end{tabular}

\footnotetext{
FRB437-1.

2 FRB437-2.
}

Modeling presented here is intended to be illustrative rather than absolute. Kd's from: garnet from Irving and Frey [44]; Cpx from Masuda and Kushiro [41]; Opx from Schnetzler and Philpotts [64]; Olivine from Arth and Hanson [65]. 


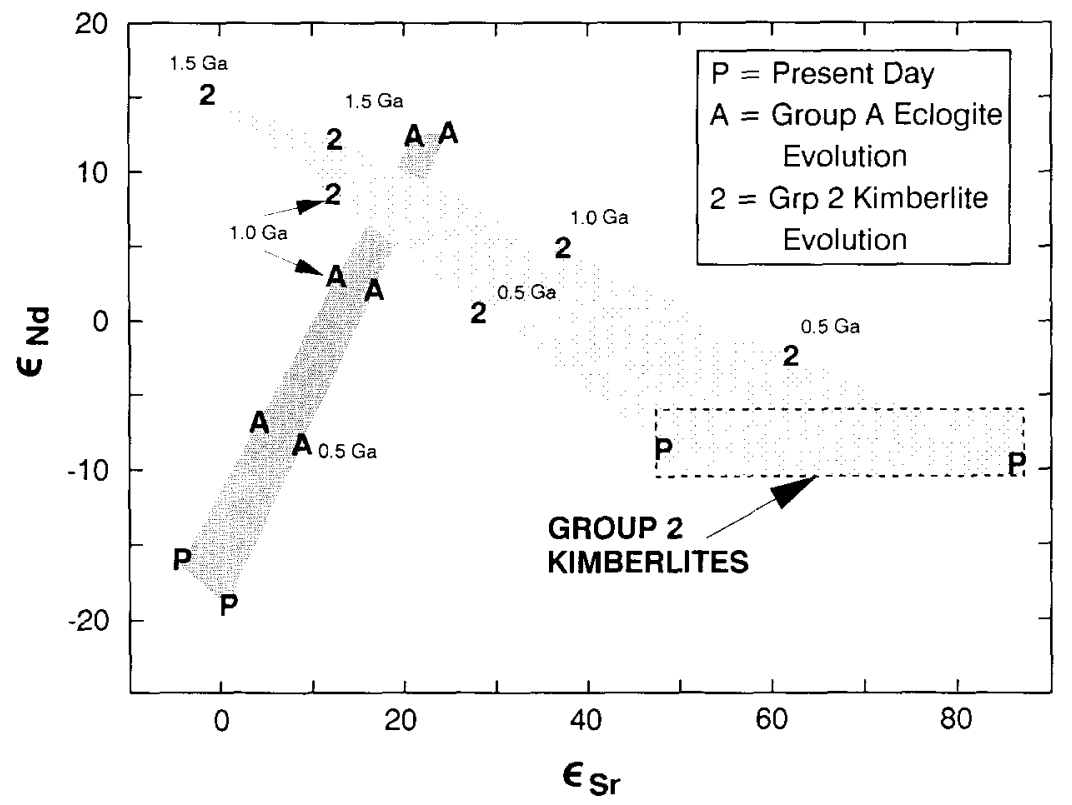

Fig. 3. $\epsilon_{\mathrm{Nd}}$ vs. $\epsilon_{\mathrm{Sr}}$ plot which demonstrates the evolution of Group A eclogites which crystallized from a Group II kimberlite magma at $\sim 1-1.2 \mathrm{Ga}$. Reconstructed whole-rock isotope values were used (Table 3). The evolution of the Group II kimberlite field is also shown (data from [30]).

could have coincided with the ratio of Group II kimberlites [30] at $\sim 1-1.5 \mathrm{Ga}$.

\subsection{Groups $B$ and $C$}

The compositions of Group B and C eclogites are similar to those of subducted oceanic crust, interpreted as the basaltic MORB-like portion (layer 2), and the plagioclase-rich, plutonic section (layer 3 ), respectively $[1,2,12,13,16-18]$. Although the isotopic data presented in this study support this general petrogenetic model, they indicate a more complex geochemical history. The data also have important implications for cryptic metasomatic processes affecting even the most carefully prepared primary phases. This process is distinct from, although related to, the patent metasomatism described by Taylor and Neal [2].

Gregory and Taylor [35], MacGregor and Manton [16], Ongley et al. [47], and Shervais et al. [1] concluded that the low $\delta^{18} \mathrm{O}$ isotopic compositions of the Group B and C eclogites can be generated only at relatively high crustal temperatures (i.e., $300-400^{\circ} \mathrm{C}$ ), and are similar to $\delta^{18} \mathrm{O}$ values of present-day, high-temperature, seawater-altered oceanic basalts [48]. The oxygen isotope results of this study are consistent with this model. The oceanic protolith was subsequently introduced, by subduction, to the relatively high pressure and temperature regime of the mantle, and preserved its low $\delta^{18} \mathrm{O}$ signature, even through the eclogite phase transformation.

The equilibrium values of oxygen isotope fractionation between clinopyroxene and garnet are not well known. Fractionations found in natural assemblages are usually less than $1 \%$ [47]. It is likely that the equilibrium fractionation for this mineral pair is intrinsically small over a wide temperature range. For example, the calculated fractionation for diopside-pyrope is $-0.34 \%$ at $800 \mathrm{~K}$ and $+0.17 \%$ at $1220 \mathrm{~K}$ [49]. Thus, the clinopyroxene-garnet isotopic fractionation serves as a sensitive test of disequilibrium between these phases. Only two samples show signs of disequilibrium: FRB437-5, for which $\Delta_{\mathrm{cpx}-\mathrm{gt}}=+0.8$, and PHN2791-34, for which $\Delta_{\text {cpx-gt }}=-0.4$. Gregory and Taylor [35] attributed oxygen isotope disequilibrium between individual mantle peridotite mineral phases as the result of differing rates of equilibration of each mineral phase with a metasomatic fluid. Ongley et al. [47] suggested a similar process for the Roberts Victor eclogites, with clinopyroxene re-equilibrating more quickly 


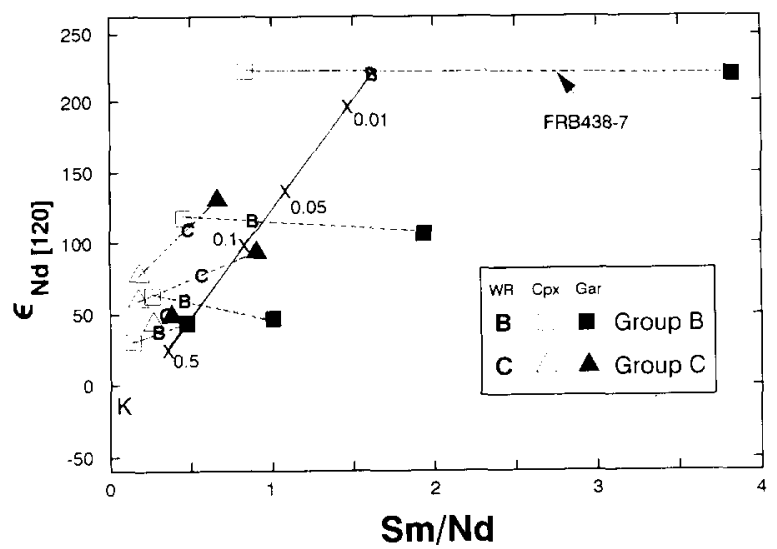

Fig. 4. $\epsilon_{\mathrm{Nd}_{d}}$ vs. $\mathrm{Sm} / \mathrm{Nd}$ for Group $\mathrm{B}$ and $\mathrm{C}$ eclogites. $W R$ represents the reconstructed whole-rock eclogites. Isotopic ratios are corrected to the age of eruption of the Bellsbank kimberlite. A mixing line has been calculated between FRB438-7, the most depleted eclogite analyzed (reconstructed values), and the Bellsbank kimberlite $(K)$. Numbers along the mixing line represent the percentage of kimberlite incorporated. Kimberlite data from Smith [30].

than garnet. The rest of our clinopyroxene-garnet pairs are within $0.3 \%$ of each other, suggesting probable oxygen isotopic equilibrium.

The $\mathrm{Sr}$ and $\mathrm{Nd}$ isotopic data are less straight forward. Both clinopyroxene and garnet mineral separates (and thus reconstructed whole-rocks) form linear relationships on an $\epsilon_{\mathrm{Nd}[120]}$ vs. $\mathrm{Sm} / \mathrm{Nd}$ plot (Fig. $4 \mathrm{a}-\mathrm{c}$ ). Regression of the reconstructed whole-rock data, comprising data from both Groups B and C yields a date of $2.1 \pm 0.2 \mathrm{Ga}$. However, the validity of this "age", in terms of yielding information on the time at which the eclogite or eclogite protolith underwent the final equilibration, must be carefully evaluated. For example, such a correlation could also be a function of mixing between two isotopically distinct end-members. If this is the case, the "date" obtained in Fig. 4 is probably meaningless.

If $\epsilon_{\mathrm{Nd}[120]}$ is plotted against $1 / \mathrm{Nd}$ for the mineral separates and reconstructed whole-rocks (Fig. 5), a positive linear relationship is observed, with the Bellsbank kimberlite plotting at the lower end. Such a relationship suggests that a possible two-component mixing process may be at least partly responsible for the observed isotopic variations of Group B and C eclogites [e.g., 50]. The end-members necessary to explain the compositional relationships illustrated in Figs. 4 and 5 are an eclogitic component with extremely high ${ }^{143} \mathrm{Nd} /{ }^{144} \mathrm{Nd}$ and low $\mathrm{Nd}$ abundances and a kimberlitic component with low ${ }^{143} \mathrm{Nd} /{ }^{144} \mathrm{Nd}$ and high $\mathrm{Nd}$ contents. These end-members may be similar to the most depleted eclogite xenolith (FRB438-7 with $\epsilon_{\mathrm{Nd}[120]}=+219 ; \mathrm{Nd}=0.13 \mathrm{ppm}$ ) and the observed Bellsbank kimberlite matrix $\left(\epsilon_{\mathrm{Nd}[120]}=-10 ; \mathrm{Nd}=182 \mathrm{ppm} ;\right.$ [30]). This model is consistent with the results of Taylor and Neal [2], who concluded that most of the patent metasomatism observed in these xenoliths resulted from interactions between the eclogites and kimberlite host magma. However, mixing relationships suggested in Figs. 4 and 5 are present in the "ultrapure" mineral separates of clinopyroxene and garnet. We are confident that these relationships are not due to impure mineral separation. Therefore, cryptic as well as patent metasomatism of the Group B and C eclogites is necessary to account for these correlations. This cryptic metasomatism may have occurred relatively recently (i.e., within the last several hundred million years). If such metasomatism were ancient, the positive correlations in Figs. 4 and 5 would show more scatter due to radioactive decay [50]. Hence, we conclude that metasomatism is related to the magmatism that produced the Bellsbank kimberlite. This magmatism was not related to that which crystallized the Group A eclogites.

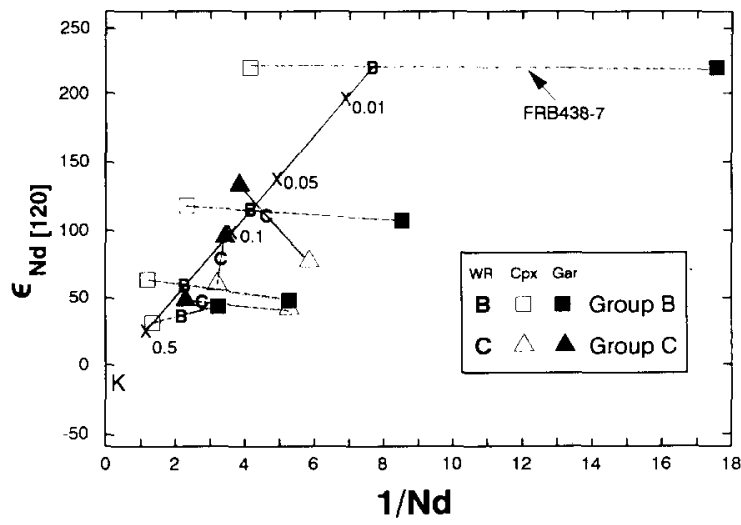

Fig. 5. $\epsilon_{\mathrm{Nd}}$ vs. $1 / \mathrm{Nd}$ for Group $\mathrm{B}$ and $\mathrm{C}$ eclogites. $W R$ represents the reconstructed whole-rock eclogites. Isotopic ratios are corrected to the age of eruption of the Bellsbank kimberlite. A mixing line has been calculated between FRB438-7, the most depleted eclogite analyzed (reconstructed values), and the Bellsbank kimberlite $(K)$. Numbers along the mixing line represent the percentage of kimberlite incorporated. Kimberlite data from Smith [30]. 
Model age calculations also provide evidence that the Group B and C eclogites have experienced some form of cryptic metasomatism. In terms of the $\mathrm{Sm} / \mathrm{Nd}$ and $\mathrm{Nd}$ isotopic ratios in the reconstructed whole-rocks, only three samples (FRB438-2, FRB438-7, and PHN2791-34) yield reasonable (although widely variable) model ages of $2.82,2.39$, and $4.24 \mathrm{Ga}$ (respectively) relative to CHUR, and 2.66, 2.32, and $3.98 \mathrm{Ga}$ (respectively) relative to a depleted mantle evolution path. All other model ages are greater than the age of the Earth, except for PHN2791-21 which has a negative age. The results of these calculations illustrate that the $\mathrm{Sm} / \mathrm{Nd}$ ratios observed in Groups B and $\mathrm{C}$ eclogites are incapable of explaining the observed present-day $\mathrm{Nd}$ isotopic compositions. Generally, the samples most affected by this cryptic metasomatism yield the oldest model ages. This is because the evolution line on an ${ }^{143} \mathrm{Nd} /{ }^{144} \mathrm{Nd}$ vs. age plot intersects the bulk earth and depleted mantle evolution lines at older ages due to the lower $\mathrm{Sm} / \mathrm{Nd}$ ratios (generated by cryptic metasomatism). The result is a lower slope on the evolution path of the sample. Therefore, various degrees of LREE-enriched cryptic metasomatism may explain the anomalously old and variable model ages observed in Group B and $\mathrm{C}$ eclogites.

Calculated mixing curves for $\epsilon_{\mathrm{Nd}[120]}$ vs. $\mathrm{Sm} / \mathrm{Nd}$ and $1 / \mathrm{Nd}$ between the Bellsbank kimberlite $\left(\epsilon_{\mathrm{Nd}[120]}=-10\right.$ and $\mathrm{Sm} / \mathrm{Nd}=0.128$; [30]) and the most depleted eclogite in our suite $\left(\mathrm{FRB} 438-7 ; \epsilon_{\mathrm{Nd}[120]}=+219\right.$ and $\mathrm{Sm} / \mathrm{Nd}=1.615$; Table 3), are shown in Figs. 4 and 5. Group C eclogites fall on this mixing line suggesting similarities between Groups B and C, but Taylor and Neal [2] argued that these eclogite groups represented distinct portions of ancient oceanic crust. However, they may have had similar initial ${ }^{143} \mathrm{Nd} /{ }^{144} \mathrm{Nd}$ ratios, as they are postulated to have been generated from a similar mantle source beneath an oceanic rift. Therefore, the most depleted eclogite from these two groups (FRB438-7) will represent an end-member composition, provided all members of the Group $\mathrm{B}$ and $\mathrm{C}$ eclogites originally contained similar $\mathrm{Nd}$ abundances. FRB438-7 may have undergone some cryptic metasomatism, but for illustrative purposes, we will assume that it is representative of the original $\mathrm{Nd}$ isotopic signature of both Group B and C

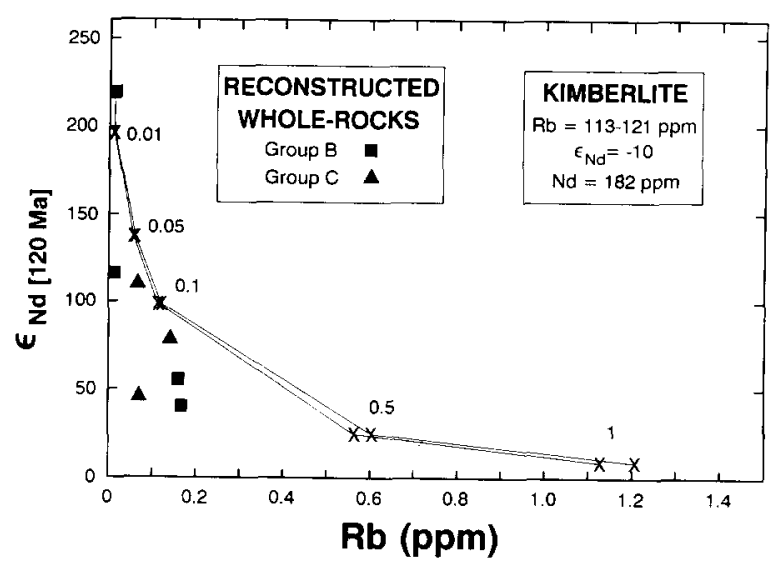

Fig. 6. $\epsilon_{\mathrm{Nd}}$ vs. $\mathrm{Rb}$ (ppm) for the Group $\mathrm{B}$ and $\mathrm{C}$ reconstructed whole-rock eclogites. Isotopic ratios are corrected to the age of eruption of the Bellsbank kimberlite. Mixing lines have been calculated between FRB438-7 and two of the Bellsbank kimberlite compositions reported by Smith [30]. Numbers along the mixing line represent the percentage of kimberlite incorporated.

eclogites. This eclogite also has the youngest model age $\left(T_{\mathrm{CHUR}}=2.39 \mathrm{Ga} ; T_{\mathrm{DM}}=2.32 \mathrm{Ga}\right)$. The results of the mixing calculations (Figs. 4 and 5) demonstrate that only a very small amount of metasomatism ( $0.5 \%$ maximum) by the Bellsbank kimberlite is required to generate the observed range in $\mathrm{Nd}$ isotopic composition. This is due in large part to the differences in $\mathrm{Nd}$ abundances between the two end-members. The isotopic composition of $\mathrm{Nd}$ in the kimberlite, which contains $182 \mathrm{ppm} \mathrm{Nd}$, can readily affect an eclogite that contains $<1 \mathrm{ppm} \mathrm{Nd}$.

The effects of cryptic metasomatism can also be demonstrated for other elements in addition to the REE. Like $\mathrm{K}, \mathrm{Rb}$ is enriched in metasomatic fluids and should be relatively abundant in eclogites that have experienced the greatest amount of metasomatism, although absolute abundances are still low $(<1 \mathrm{ppm}) . \epsilon_{\mathrm{Nd} \text { [120] }}$ variations are plotted against $\mathrm{Rb}(\mathrm{ppm})$ for the reconstructed wholerocks (Fig. 6) and show that eclogites with the lowest $\epsilon_{\mathrm{Nd} \mathrm{[120]}}$ compositions generally contain the highest concentrations of $R \mathbf{b}$, but also that the degree of contamination is nearly identical between that calculated from $\mathrm{Rb}$ and for the $\mathrm{Nd}$ mixing models (Figs. 4 and 5). In both cases, the $\mathrm{Nd}$ and $\mathrm{Rb}$ in eclogites with the lowest $\epsilon_{\mathrm{Nd}}$ need only be contaminated with between 0.1 and $0.5 \%$ of the kimberlitic component. In view of the prep- 


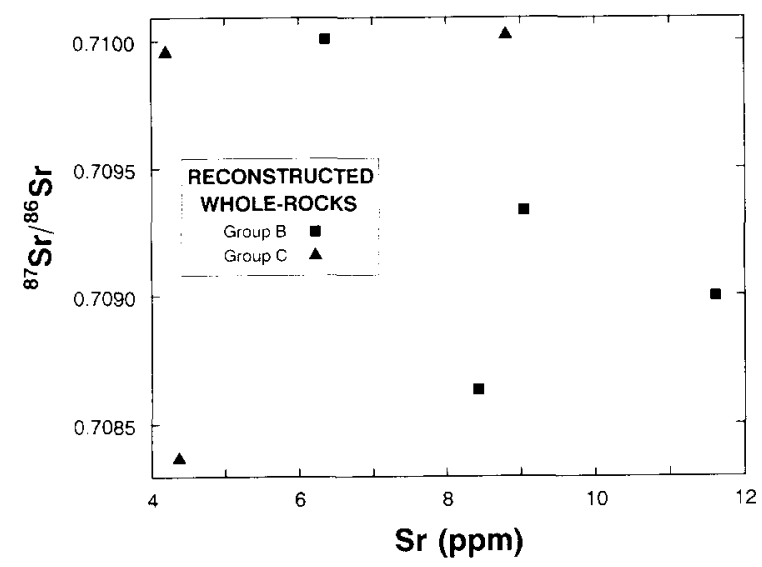

Fig. $7 .{ }^{87} \mathrm{Sr} /{ }^{86} \mathrm{Sr}$ vs. Sr (ppm) for Group B and C reconstructed whole-rock eclogites. Isotopic ratios are corrected to the age of eruption of the Bellsbank kimberlite. The lack of a linear correlation indicates that simple two component mixing was not responsible for the generation of the $\mathrm{Sr}$ isotopes and abundances of these eclogites.

aration given to the minerals it is clear that the $\mathrm{Rb}$ analyzed is derived from the mineral itself rather than from surficial contamination.

The Sr isotopic compositions of Group B and C eclogites are not consistent with the simple twocomponent mixing model developed above. There is a lack of correlation between ${ }^{87} \mathrm{Sr} /{ }^{86} \mathrm{Sr}$ and $\mathrm{Sr}$ (ppm) (Fig. 7). All reconstructed whole-rocks possess radiogenic ${ }^{87} \mathrm{Sr} /{ }^{86} \mathrm{Sr}$ ratios (up to 0.71006 at the time of kimberlite eruption: Tables 1 and 3, Fig. 2). The high ${ }^{87} \mathrm{Sr} /{ }^{86} \mathrm{Sr}$ ratios observed in these xenoliths could not have been generated in a closed system, given the observed low $\mathrm{Rb} / \mathrm{Sr}$ ratios, even over 2.3-2.4 Ga suggested by the $T_{\mathrm{BE}}$ and $T_{\mathrm{DM}}$ $\mathrm{Nd}$ model ages.

The reconstructed whole-rock $\mathrm{Sr}$ isotopic compositions of the Group B and C eclogites are generally higher than those of the kimberlite at the time of emplacement. Indeed, the most depleted eclogite end-member based on $\mathrm{Nd}$ isotopic composition (FRB438-7) also contains one of the most radiogenic ${ }^{87} \mathrm{Sr} /{ }^{86} \mathrm{Sr}$ ratios $(0.71002)$. This observation indicates that cryptic metasomatism by the Bellsbank kimberlite magmatism was not responsible for generating these high $\mathrm{Sr}$ isotopic compositions. However, it could be responsible for lowering the ${ }^{87} \mathrm{Sr} /{ }^{86} \mathrm{Sr}$ ratios of the eclogites from an initial ${ }^{87} \mathrm{Sr} /{ }^{86} \mathrm{Sr}$ of $-0.710-0.711$. Possibly an additional mixing or metasomatic process is required, other than the one described above for the
Nd isotopes, to account for the ${ }^{87} \mathrm{Sr} /{ }^{86} \mathrm{Sr}$ ratios of the Group B and C eclogites.

If we assume that these eclogites do indeed represent ancient subducted oceanic crust, there are only a limited number of possible mechanisms that may be envisaged by which radiogenic $\mathrm{Sr}$ could be generated. The radiogenic $\mathrm{Sr}$ isotopic composition could not have been generated from the ${ }^{87} \mathrm{Rb} /{ }^{86} \mathrm{Sr}$ ratios of basaltic rocks by decay in the time between formation as oceanic crust and eclogite transformation. Seawater alteration products could clearly be a component in the eclogite protolith. The measured $\mathrm{Sr}$ isotopic composition of Archean/Proterozoic seawater, though not well defined from Precambrian carbonates, generally appears to fall within the range $0.7007-0.7128$ [51-55]. Furthermore, Dasch et al. [56] and Menzies and Seyfried [57] reported that seawateraltered basalts can possess ${ }^{87} \mathrm{Sr} /{ }^{86} \mathrm{Sr}$ ratios which were greater than that of the interacting seawater.

For any model to be suitable, the high ${ }^{87} \mathrm{Sr} /{ }^{86} \mathrm{Sr}$ ratios need to be generated before the eclogite phase transformation occurs. During eclogite transformation, $\mathrm{Rb}$ has been preferentially lost along with the LREEs. The high ${ }^{87} \mathrm{Sr} /{ }^{86} \mathrm{Sr}$ ratios are preserved within the Group $\mathrm{B}$ and $\mathrm{C}$ eclogites as the resulting low ${ }^{87} \mathrm{Rb} /{ }^{86} \mathrm{Sr}$ ratios have had little affect upon the isotopic ratio. The scatter produced in the $\mathrm{Sr}$ isotopic ratios of Group B and $\mathrm{C}$ eclogites is probably a function of heterogeneities in the protolith, coupled with cryptic metasomatism by the Bellsbank kimberlite. Group A eclogites remained relatively unaffected because of their high abundances of $\mathrm{Nd}$ and $\mathrm{Sr}$. A greater amount of kimberlite metasomatism than the postulated $0.5 \%$ would be required in order to swamp the primary isotopic signature. Such processes can account for the scattered distribution of $\mathrm{Sr}$ isotopes and abundances from Group B and C eclogites in Fig. 7.

\section{Garnet-clinopyroxene mineral pairs}

Both trace and major elements are partitioned preferentially into clinopyroxene or garnet, but both phases should have identical isotopic compositions at the time of eclogite formation. Variations observed in isotopic compositions between mineral pairs should then be attributable to differences in the ratios of $\mathrm{Rb} / \mathrm{Sr}$ and $\mathrm{Sm} / \mathrm{Nd}$ incor- 

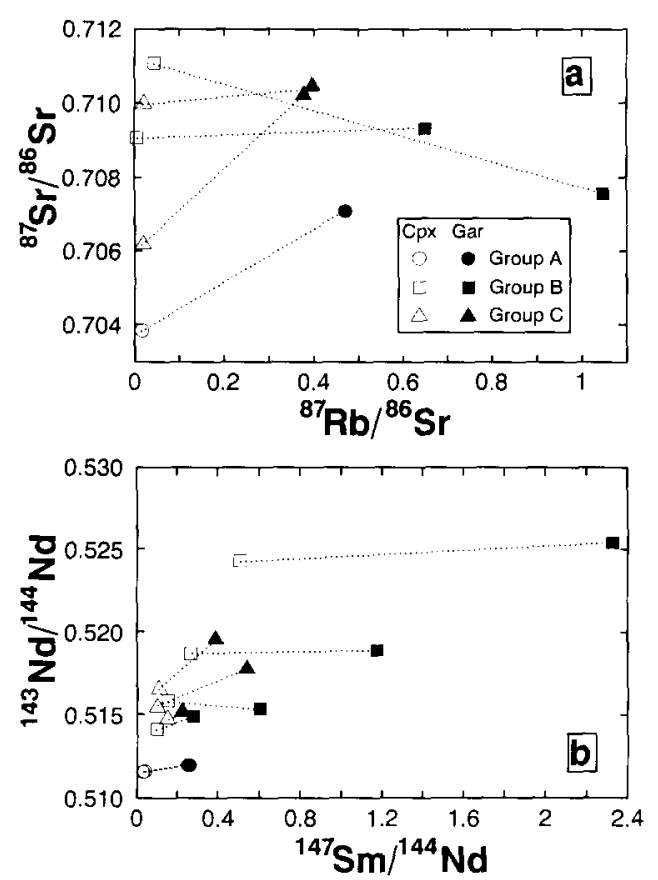

Fig. 8. $\mathrm{Rb}-\mathrm{Sr}$ and $\mathrm{Sm}-\mathrm{Nd}$ isochron diagrams for garnet and clinopyroxene mineral separates. Present-day isotope ratios are used (Table 1). Only five samples are plotted in 8 a because of the lack of $\mathrm{Sr}$ isotope data for garnet in four samples.

porated into each phase and the time elapsed since equilibration between the phases. Therefore, mineral pairs should yield two point isochrons, reflecting the time of cooling of the eclogite below the temperature at which efficient exchange of $\mathrm{Sr}$ and $\mathrm{Nd}$ between the constituent minerals ceased [58]. Garnet-clinopyroxene pairs from individual Group B and $\mathrm{C}$ eclogites contain ${ }^{143} \mathrm{Nd} /{ }^{144} \mathrm{Nd}-$ ${ }^{147} \mathrm{Sm} /{ }^{144} \mathrm{Nd}$ and ${ }^{87} \mathrm{Sr} /{ }^{86} \mathrm{Sr}-{ }^{87} \mathrm{Rb} /{ }^{86} \mathrm{Sr}$ relationships which yield both positive and negative slopes (Fig. 8). This lack of coherence clearly indicates that at least one of the conditions required for closed-system isotope evolution has not been met. Furthermore, it is quite conceivable that the proposed metasomatic events were complicated by differing degrees or, possibly, rates of equilibration between garnet-fluid and clinopyroxene-fluid within the same rock, as shown by the oxygen isotopes. Once isotopic equilibrium was established, further cooling could effectively eliminate $\mathrm{Nd}$ and $\mathrm{Sr}$ exchange between coexisting clinopyroxene and garnet, allowing the isotopic compositions to evolve independently without having first re-homogenized. Although Jagoutz [58] sug- gested that isotopic disequilibrium between mineral pairs could yield meaningful information regarding the thermal history of eclogite xenoliths, we stress that any such age relationships found in the Bellsbank eclogites may be artifacts of the various metasomatic processes that have affected these xenoliths. We also emphasize that reported "dates" for even the cleanest-looking mantle samples must be interpreted with great caution until the possibilities of cryptic metasomatism have been fully evaluated.

\section{Generation of highly depleted end-member com- positions}

Generation of the extremely depleted $\mathrm{Nd}$ isotopic compositions observed in these eclogites, especially FRB438-7 (which has $\epsilon_{\mathrm{Nd}[120]}=+219$ ), requires a high $\mathrm{Sm} / \mathrm{Nd}$ and a long period of time. The $\mathrm{Sm} / \mathrm{Nd}$ ratios observed in present-day MORB or in most Archean komatiites cannot generate the present-day eclogite $\epsilon_{\mathrm{Nd}}$ values, even over a period of $\sim 2.4 \mathrm{Ga}$ (see above). Even though partial melting of the subducted slab may increase the LREE-depletion of the protolith, this process still cannot generate the required $\mathrm{Sm} / \mathrm{Nd}$ ratios. For example, partial melting calculations on modern MORB using both modal and non-modal models, typical mineralogies, and a range of accepted mineral-liquid Kd's result in $\mathrm{Sm} / \mathrm{Nd}$ values of less than 0.85 (compared with a value of 1.615 for FRB438-7).

One way to generate such high $\mathrm{Sm} / \mathrm{Nd}$ ratios is during the transformation of oceanic crust to eclogite, if it is assumed that an incompatibleelement-rich fluid phase is lost (i.e., the recrystallization is not a closed system). LIL-enriched metasomatic fluids derived from the subducting plate have been proposed to explain variations in the composition of arc magmas [e.g., 59-61]. These fluids could be complementary to the extremely depleted eclogitic slab residue in this study. Furthermore, Ringwood [62] suggested that during eclogite transformation, a hydrous fluid was produced and driven off. Quantification of this process is not possible due to a lack of relevant experimental data. Wilson and Carlson [63] reported $\mathrm{Sm}-\mathrm{Nd}$ data for komatiites from an Archean greenstone belt in the southern Kaapvaal craton, defined as the Matshenpondo peridotite 
suite. These komatiites contain $\mathrm{Sm} / \mathrm{Nd}$ ratios up to 1.08 and present-day $\epsilon_{\mathrm{Nd}}$ up to +196 . These authors attribute the high $\mathrm{Sm} / \mathrm{Nd}$ to orthopyroxene enrichment or accumulation. It is feasible that subduction of such a Greenstone Belt assemblage beneath the Kaapvaal craton could generate the observed eclogite $\mathrm{Sm} / \mathrm{Nd}$ ratio of our depleted end-member during phase transformation. Further work is underway to substantiate this preliminary supposition.

7. Summary: models for Bellsbank eclogite petrogenesis (Fig. 9)

\subsection{Group $A$}

Group A eclogites can be generated by crystal fractionation of garnet and clinopyroxene from a kimberlitic or proto-kimberlitic magma within the upper mantle. Trace element (REE) and isotope modeling indicate that this magma was consistent with Group II kimberlite.

\subsection{Groups $B$ and $C$}

Group B eclogites represent the basaltic (dike) portion and Group $\mathrm{C}$, the plagioclase-rich cumulate portion of oceanic crust. Isotopic compositions of Group B and C eclogites preserve evidence for a long and complex geochemical history, involving an ancient LREE-depletion. The $\mathrm{Sr}$ isotopic compositions $\left({ }^{87} \mathrm{Sr} /{ }^{86} \mathrm{Sr}\right.$ ratios of $0.710_{-}$ 0.711 ), may have been produced by seawater alteration of oceanic crust before subduction. The range in $\mathrm{Nd}$ isotopic composition was generated in response to the magmatism that resulted in the generation of the Bellsbank kimberlite. This lowered both the $\epsilon_{\mathrm{Nd}[120]}$ and ${ }^{87} \mathrm{Sr} /{ }^{86} \mathrm{Sr}$ signatures of the eclogites and also resulted in extensive patent metasomatism of the Group B and C eclogite xenoliths (Taylor and Neal [2]), but only limited cryptic metasomatism of the primary phases. Identification of the effects of cryptic metasomatism in these xenoliths masks the ability to isolate pertinent details of the primary compositional variations of eclogite protoliths. However, variations observed within the suite allow the composition of mixing end-members to be estimated, and qualitative models which may constrain processes occurring within the upper mantle underlying the Kaapvaal craton to be developed. The $\delta^{18} \mathrm{O}$ values are consistent with high-temperature seawater circulation at a mid-ocean ridge; we suggest that the extreme $\mathrm{Sm} / \mathrm{Nd}$ ratios required can be produced during the open system recrystallization of basalt or komatiite to eclogite at - $2.4 \mathrm{Ga}$.

This study highlights the role of even very small

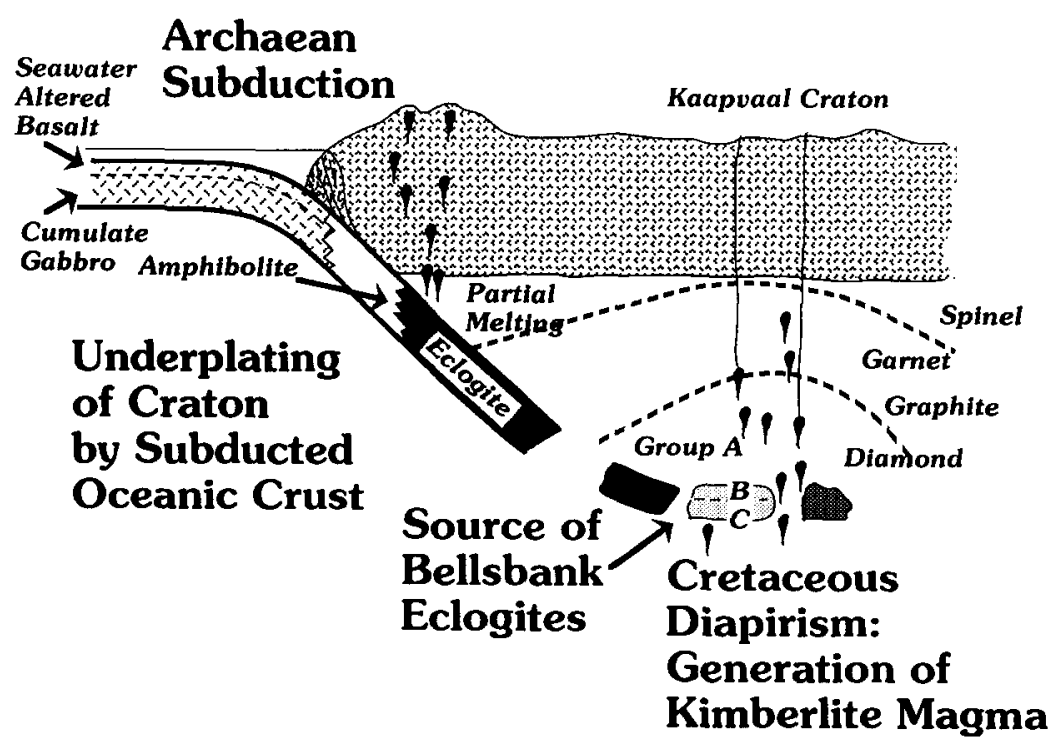

Fig. 9. Cartoon representation of Bellsbank eclogite petrogenesis. 
amounts of cryptic metasomatism in producing fictitious model and isochron ages. The isotope data presented above are consistent with the conclusions of Shervais et al. [1] and Taylor and Neal [2].

\section{Acknowledgements}

Complete and thoughtful reviews from two anonymous reviewers and Charles $\mathrm{H}$. Langmuir have greatly improved this manuscript. Samples prefixed by FRB were donated by Joe Boyd who is gratefully acknowledged for his assistance in starting this project. This research was supported by NASA grant NAG 9-336 to L.A.T., NSF grants EAR-8616061 and 8720564 to A.N.H. and NSF grant EAR-8616255 to R.N.C.

\section{References}

1 J.W. Shervais, L.A. Taylor, G. Lugmair, R.N. Clayton, T.K. Mayeda and R. Korotev, Archean oceanic crust and the evolution of sub-continental mantle: Eclogites from southern Africa, Geol. Soc. Am. Bull. 100, 411-423, 1988.

2 L.A. Taylor and C.R. Neal, Eclogites with oceanic crustal and mantle signatures from the Bellsbank kimberlite, South Africa, Part 1: Mineralogy, petrography, and whole-rock chemistry, J. Geol. 97, 551-567, 1989.

3 M.J. O'Hara, and H.S. Yoder Jr., Formation and fractionation of basic magmas at high pressures, Scott. J. Geol. 3, 67-117, 1967.

4 I.D. MacGregor and J.L. Carter, The chemistry of clinopyroxene and garnets of eclogite and peridotite xenoliths from the Roberts Victor mine, South Africa: Physics Earth Planet. Inter. 3, 391-397, 1970.

5 C.J. Hatton. The geochemistry and origin of xenoliths from the Roberts Victor Mine, Unpubl. Ph.D. Thesis, University of Cape Town, South Africa, 179 pp, 1978.

6 J.R. Smyth and F.A. Caporuscio, Petrology of a suite of eclogite inclusions from the Bobbejaan kimberlite: II. Primary phase compositions and origin, in: Kimberlites II: The Mantle and Crust-Mantle Relationships, J. Kornprobst, ed., pp. 121-132, Elsevier, Amsterdam, 1984.

7 J.R. Smyth, T.C. McCormick and F.A. Caporuscio, Petrology of a suite of eclogite inclusions from the Bobbejaan kimberlite: I. Two unique corundum grospydites, in: Kimberlites II: The Mantle and Crust-Mantle Relationships, J. Kornprobst, ed., pp. 109-120, Elsevier, Amsterdam, 1984.

8 J.R. Smyth, F.A. Caporuscio and T.C. McCormick, Mantle eclogites: Evidence of igneous fractionation in the mantle, Earth Planet. Sci. Lett. 93, 133-141, 1989.

9 H. Helmstaedt and R. Doig, Eclogite nodules from kimberlite pipes of the Colorado Plateau-samples of Franciscan-type oceanic lithosphere, Phys. Chem. Earth 9, $95-111,1975$.
$10 \mathrm{H}$. Helmstaedt and D.J. Schulze, Garnet clinopyroxenechlorite eclogite transition in xenoliths from Moses Rock: Further evidence for metamorphosed ophiolites under the Colorado Plateau, in: The Mantle Sample: Inclusions in kimberlites and other volcanics, F.R. Boyd and H.O.A. Meyer, eds., pp. 357-365, AGU, Washington, D.C., 1979.

11 P.C. Ater, D.H. Eggler and M.E. McCallum, Petrology and geochemistry of mantle eclogite xenoliths from ColoradoWyoming kimberlites: re-cycled oceanic crust? in: Kimberlites II: Mantle and Crust-Mantle Relationships, J. Kornprobst, ed., pp. 309-318, Elsevier, Amsterdam, 1984.

12 E. Jagoutz, J.B. Dawson, S. Hoernes, B. Spettel and H. Wänke, Anorthositic oceanic crust in the Archean Earth, Lunar Planet. Sci. XV, 395-396, The Lunar and Planetary Institute, Houston Tex., 1984.

13 E. Jagoutz, J.B. Dawson, S. Hoernes, B. Spettel and H. Wänke, Anorthositic oceanic crust in the Archean Earth, LPI Tech. Rep. 85-01, 40-41, The Lunar and Planetary Institute, Houston, Tex., 1985.

14 S.E. Haggerty, 1986, Diamond genesis in a multiply-constrained model, Nature 320, 34-36, 1986.

15 D.J. Schulze, Calcium anomalies in the mantle and a subducted metaserpentinite origin for diamonds, Nature 319 , 483-485, 1986.

16 I.D. MacGregor and W.I. Manton, The Roberts Victor eclogites: Ancient oceanic crust: J. Geophys. Res. 91, 14063-14079, 1986.

17 J.W. Shervais, L.A. Taylor and R.L. Korotev, Petrology and mineral chemistry of some African eclogites and the evolution of sub-continental mantle and continental crust, Lunar Planet. Sci. XVI, 769-770, The Lunar and Planetary Institute, Houston, Tex., 1985.

18 J.W. Shervais, L.A. Taylor, G. Lugmair, R.N. Clayton, T.K. Mayeda and R. Korotev, Evolution of sub-continental mantle and crust: Eclogites from southern Africa, Extended Abstr. 4th Int. Kimberlite Conf., Geol. Soc. Aust. Publ. 16 , 326-328, Perth, 1986.

19 C.R. Neal, L.A. Taylor, P. Holden, J.P. Davidson, A.N. Halliday, R.N. Clayton and T.K. Mayeda, Unique isotopic signatures of eclogite xenoliths as evidence of ancient plate tectonic processes, Lunar Planet. Sci., XX, 774-775. Lunar and Planetary Institute, Houston, Tex., 1989.

20 D.L. Anderson, Hotspots, basalts, and the evolution of the mantle, Science 213, 82-89, 1981 a.

21 D.L. Anderson, A global model for the evolution of the mantle, in: Evolution of the Earth Geodynamics Series 5 . pp. 6-18, AGU Washington, 1981b.

22 M.T. McCulloch, Identification of the Earth's earliest differentiates, in: 5th Int. Conf. Geo. Cosmo. Isot. Geol., pp. 244-246, Nikko, Japan, 1986.

23 M.T. McCulloch, Sm-Nd systematics in eclogite and garnet peridotite nodules from kimberlites: Implications for the early differentiation of the Earth, in: Kimberlites and Related Rocks II: Their Mantle/Crust Setting, Diamonds, and Diamond Exploration, pp. 864-876, Blackwell, Oxford, 1989.

24 P.H. Warren and J.T. Wasson, The origin of KREEP, Rev. Geophys. Space Phys. 17, 73-88, 1979.

25 P.H. Warren, The magma ocean concept and lunar evolution, Annu. Rev. Earth Planet. Sci. 13, 201-240, 1985. 
26 R.G. Coleman, E.D. Lee, L.B Beatty and W.W. Brannock, Eclogites and eclogites: Their differences and similarities, Geol. Soc. Am. Bull. 76, 483-508, 1965.

27 J.F. Lovering and M. Tatsumoto, Lead isotopes and the origin of granulite and eclogite inclusions in deep-seated pipes, Earth Planet. Sci. Lett. 4, 350-358, 1968.

28 H.L. Allsopp, L.O. Nicolaysen and P. Hahn-Weinheimer, $\mathrm{Rb} / \mathrm{K}$ ratios and $\mathrm{Sr}$ isotopic compositions of minerals in eclogitic and peridotitic rocks, Earth Planet. Sci. Lett. 5, 231-239, 1969.

29 W.I. Manton and M. Tatsumoto, Some $\mathrm{Pb}$ and $\mathrm{Sr}$ isotopic measurements on eclogites from the Roberts Victor Mine, South Africa, Earth Planet. Sci. Lett. 10, 217-226, 1971.

$30 \mathrm{C} . \mathrm{B}$. Smith, $\mathrm{Pb}, \mathrm{Sr}$, and $\mathrm{Nd}$ isotopic evidence for sources of southern African Cretaceous kimberlites, Nature 304, 51 $54,1983$.

31 R.N. Clayton and T.K. Mayeda, The use of bromine pentafluoride in the extraction of oxygen from oxides and silicates for isotopic analysis, Geochim. Cosmochim. Acta 27. 43-52, 1963.

32 S.H. Richardson, A.J. Erlank and S.R. Hart, Kimberliteborne garnet peridotite xenoliths from old enriched subcontinental lithosphere, Earth Planet. Sci. Lett. 75, 116-128, 1985.

33 T.K. Kyser, J.R. O'Neil and I.S.E. Carmichael, Oxygen isotope thermometry of basic lavas and mantle nodules, Contrib. Mineral. Petrol. 77. 11-23, 1981.

34 R.T. Gregory and H.P. Taylor Jr., An oxygen isotope profile in a section of Cretaceous oceanic crust, Samail ophiolite, Oman: Evidence for ${ }^{18} \mathrm{O}$-buffering of the oceans by deep $(>5 \mathrm{~km})$ seawater-hydrothermal circulation at mid-ocean ridges, J. Geophys. Res. 86, 2737-2755, 1981.

35 R.T. Gregory and H.P. Taylor Jr., Non-equilibrium, metasomatic ${ }^{18} \mathrm{O} /{ }^{16} \mathrm{O}$ effects in upper mantle mineral assemblages, Contrib. Mineral. Petrol. 93, 124-135, 1986.

36 C.M. Graham and R.S. Harmon, 1983, Stable isotope evidence on the nature of crust-mantle interactions, in: Continental Basalts and Mantle Xenoliths, C.J. Hawkesworth and M.J. Norry, eds., 20-45, Shiva, U.K., 1983.

37 H.W. Fesq, E.J.D. Kable and J.J. Gurney, Aspects of the geochemistry of kimberlites from the Premier Mine and other selected South African occurrences with particular reference to the rare earth elements, Phys. Chem. Earth 9, 687-707, 1975.

38 C.J. Hawkesworth, J.S. Marsh, A.R. Duncan, A.J. Erlank and M.J. Norry, The role of continental lithosphere in the generation of the Karoo volcanic rocks: Evidence from combined $\mathrm{Nd}$ and $\mathrm{Sr}$ isotope studies, Geol. Soc. S. Afr. Spec. Publ. 13, 341-354, 1984.

39 A.W. Hofmann and W.M. White, Mantle plumes from ancient oceanic crust, Earth Planet. Sci. Lett. 57, 421-436, 1982.

40 A.N. Halliday, A.P. Dickin, A.E. Fallick and J.G. Fitton, Mantle dynamics: A Nd, $\mathrm{Sr}, \mathrm{Pb}$, and $\mathrm{O}$ isotopic study of the Cameroon line volcanic chain, J. Petrol. 29, 181-211, 1988.

41 A. Masuda and I. Kushiro, Experimental determination of the partitioning of ten REE and Ba between clinopyroxene and liquid in the synthetic silicate system at $20 \mathrm{kbar}$ pressure, Contrib. Mineral. Petrol. 26, 42-49, 1970.
42 M. Grutzeck, S. Kridelbaugh and D. Weill, The distribution of $\mathrm{Sr}$ and REE between diopside and silicate liquid, Geophys. Res. Lett. 1, 273-275, 1974.

43 N. Shimizu and I. Kushiro, The partitioning of REE between garnet and liquid at high pressures: Preliminary experiments, Geophys. Res. Lett. 2, 413-416, 1975.

44 A.J. Irving and F.A. Frey, Distributions of trace elements between garnet megacrysts and host volcanic liquids of kimberlitic to rhyolitic composition, Geochim. Cosmochim. Acta 42, 771-787, 1978.

45 R.H. Mitchell and A.O. Brunfelt, Rare earth element geochemistry of kimberlite, Phys. Chem. Earth 9, 671-686. 1975.

46 R.H. Mitchell, Kimberlites: Mineralogy, Geochemistry, and Petrology, 300 pp., Plenum, New York, N.Y., 1986.

47 J.S. Ongley, A.R. Basu and T.K. Kyser, Oxygen isotopes in coexisting garnets, clinopyroxenes, and phlogopites of Roberts Victor eclogites: Implications for petrogenesis and mantle metasomatism, Earth Planet. Sci. Lett. 83, 80-84. 1987.

48 K. Muehlenbachs and R.N. Clayton, Oxygen isotope geochemistry of submarine greenstones. Can. J. Earth Sci. 9, 471-478, 1972.

49 S.W. Kieffer, Thermodynamics and lattice vibrations of minerals: 5, Applications to phase equilibria, isotopic fractionation, and high pressure thermodynamic properties, Rev. Geophys. Space Phys. 20, 827-849, 1982.

50 C.J. Hawkesworth and R. Vollmer, 1979, Crustal contamination versus enriched mantle: ${ }^{143} \mathrm{Nd} /{ }^{144} \mathrm{Nd}$ and ${ }^{87} \mathrm{Sr} /{ }^{86} \mathrm{Sr}$ evidence from the Italian volcanics, Contrib. Mineral. Petrol. 69, 151-165, 1979.

51 A.K. Gibbs, C.W. Montgomery, P.A. O'Day and E.A. Erslev, The Archean-Proterozoic transition: Evidence from the geochemistry of metasedimentary rocks of Guyana and Montana, Geochim. Cosmochim. Acta 50, 2125-2141, 1986.

$52 \mathrm{~J}$. Veizer, ${ }^{87} \mathrm{Sr} /{ }^{86} \mathrm{Sr}$ evolution of seawater during geologic history and its significance as an index of crustal evolution, in: The Early History of the Earth, B.F. Windley, ed., pp. 369-378, Wiley-Interscience, London, 1976.

53 J. Veizer, Strontium isotopes in seawater through time, Annu. Rev. Earth Planet. Sci. 17 (in press).

$54 \mathrm{~J}$. Veizer and $\mathrm{W}$. Compston, ${ }^{87} \mathrm{Sr} /{ }^{86} \mathrm{Sr}$ in Precambrian carbonates as an index of crustal evolution, Geochim. Cosmochim. Acta 40, 905-914, 1976.

55 J. Veizer, W. Compston, J. Hoefs and H. Nielsen, Mantle buffering of the early oceans, Naturwissenschaften 69,173 $180,1982$.

56 E.J. Dasch, C.E. Hedge and J. Dymond, Effect of seawater interaction on strontium isotope composition of deep sea basalts, Earth Planet. Sci. Lett. 19, 177-187, 1973.

57 M.A. Menzies and W.E. Seyfried, Basalt-seawater interaction: Trace element and strontium isotopic variations in experimentally altered glassy basalt, Earth Planet. Sci. Lett. 44, 463-472, 1979.

58 E. Jagoutz, $\mathrm{Nd}$ and $\mathrm{Sr}$ systematics in an eclogite xenolith from Tanzania: Evidence for frozen mineral equilibria in the continental lithosphere, Geochim. Cosmochim. Acta 52, 1285-1293, 1988.

59 M.J. Hole, A.D. Saunders, G.F. Marriner and J.T. Tarney, Subduction of pelagic sediments: Implications for the origin 
of Ce-anomalous basalts from the Mariana Islands, J. Geol. Soc. London 141, 453-472, 1984.

60 Y. Tatsumi, D.L. Hamilton and R.W. Nesbitt, Chemical characteristics of fluid phase released from a subducted lithosphere and origin of arc magmas: Evidence from high pressure experiments and natural rocks, J. Volcanol. Geotherm. Res. 29, 293-309, 1986.

61 O. Ujike, Probable mineralogic control on the mantle metasomatic fluid composition beneath the Northeast Japan arc, Geochim. Cosmochim. Acta 52, 2037-2046, 1988.

62 A.E. Ringwood, Composition and Petrology of the Earth's Mantle, 618 pp., McGraw-Hill, New York, N.Y., 1975.
63 A.H. Wilson and R.W. Carlson, $\mathrm{A} \mathrm{Sm-Nd}$ and $\mathrm{Pb}$ isotope study of Archean greenstone belts in the southern Kaapvaal Craton, South Africa, Earth Planet. Sci. Lett., 96, 89-105.

64 C.C. Schnetzler and J.A. Philpotts, Partition coefficients of REE between igneous matrix material and rock-forming mineral phenocrysts-II, Geochim. Cosmochim. Acta 34 , 331-340, 1970.

65 J.G. Arth and G.N. Hanson, Geochemistry and origin of early Pre-Cambrian crust of north-eastern Minnesota, Geochim. Cosmochim. Acta 39, 325-362, 1975. 